\title{
Chronicles of Consumer-Brand Experience: A Systematic Review and Research Agenda
}

\author{
Sara Amoroso ${ }^{1}$ \\ ${ }^{1}$ Department of Management and Law, University of Rome “Tor Vergata", Italy \\ Correspondence: Sara Amoroso, Department of Management and Law, University of Rome "Tor Vergata", \\ Columbia Street 2 - 00133, Rome, Italy. E-mail: sara.amoroso@uniroma2.it
}

Received: January 13, 2019 Accepted: February 6, $2019 \quad$ Online Published: February 25, 2019

doi:10.5539/ijms.v11n1p100 URL: https://doi.org/10.5539/ijms.v11n1p100

\begin{abstract}
This study makes an effort to unify and consolidate the concept of experience in marketing research by analyzing all the academic articles since its inception in a systematic way. The review of existing literature reveals gaps in the conceptualization, definition, relations and measurement of Consumer-Brand Experience (CBEx) from theoretical and practical perspectives. Therefore, this study significantly contributes by exploring and discussing the concept of CBEx, proposing a definition, describing its state of the art dimensions, relationships and measurement. A new and broader conceptual model is provided too. This work also highlights important challenges for future research and practice. Academics and managers are called to consider CBEx as a key determinant of consumer behavior and as an important strategic objective for brands. In particular, CBEx is the key to creating uniqueness and long-lasting brands so managers should take into account this concept in defining their marketing strategies.
\end{abstract}

Keywords: consumer experience, brand experience, consumer behavior, systematic literature review, research agenda

\section{Introduction}

Brands have been essential in building durable relations with consumers for several years ensuring long-term business success. However, in this time of consumer skepticism toward brands, influenced also from the digital environment, economic crisis, new life-style and the new peer to peer relationship between customers and brands, an innovative way to conceive brands is required.

In this scenario, the concept of experience has emerged as an important marketing driver anticipating unique, satisfying and memorable experiences and it has gained greater attention during these years. Furthermore, over the past three decades, marketing literature has emphasized the need to create better and more unique consumer experiences in order to develop stronger brands (Keller \& Lehmann, 2006; Morrison \& Crane, 2007). Thus, the concept of experience has become even more important also for marketing management. Actually, the idea that consumers are searching for unique and meaningful experiences is not new and it is well established among managers and academics. In their influential and historical introduction contained in the seminal paper on Consumption Experience, Holbrook and Hirschman (1982, p. 132) state that "Consumption has begun to be seen as involving a steady flow of fantasies, feelings, and fun encompassed by what we call the "experiential view"." Schmitt (1999, p. 53) opined that "companies have moved away from traditional "features-and-benefits" marketing toward creating experiences for their customers." Along this line, Prahalad and Ramaswamy (2004) point out organizations are redefining their offerings in terms of "personalized co-created experiences."

The relevance of this topic is also underlined by the Marketing Science Institute $(2014,2016,2018)$ that recognizes customer experience as one of its most important research challenges of these years.

The importance of CBEx is also acknowledged by the fact that consumers are not at all rational in their decisions and the evaluation about price and other technical and functional features are only a little part of consumer's behavior. In other words, consumers - now more than ever - do not just buy goods or services; they buy brands and the emotions correlated to it.

This school of thought believes that experiences resulting from various interactions with brands have a substantial impact on consumer behavior (Brakus et al., 2009; Pine \& Gilmore, 1998; Schmitt, 1999). Thanks to 
its nature this construct can be labelled as Consumer-Brand Experience (CBEx) to emphasize the relational and dyadic essence.

In fact, a consumer may establish a deep and meaningful relationship with a brand (Fournier 1998); he becomes emotionally attached to it (Thomson et al., 2005) and uses it to express his personality (Swaminathan et al., 2009) and his social self (Escalas \& Bettman 2005). Thus, if a brand betrays the consumer, the consumer-brand relationship becomes similar to a relationship cut-off (Aaker et al., 2004; Grégoire et al., 2009; Johnson et al., 2010). Instead, providing unique and memorable experiences allows firms to make stronger consumer-brand relationships and increase the success of performance outcomes (Chang \& Chieng, 2006; Ramaseshan \& Stein, 2014).

In this scenario, scholars have acknowledged the importance of the CBEx concept in the marketing, branding and consumer behavior literature and this is evident by the increasing amount of research in the marketing experience field.

However, to better understand Consumer-Brand Experience (CBEx) and its conceptualization in this complicated environment, broader knowledge of this construct is required.

\section{Aim of the Study}

Living a positive experience today, more than so in the past, seems to be one of the cornerstones of consumers when they interact with a brand. Moreover, because the experience concept has become one of the most important buzzwords in marketing, it is particularly an effort to bring together what it is known to provide a solid theoretical perspective on this topic. Despite this consensus, the CBEx phenomenon is still fragmented and it is limited by a lack of conceptual clarity. In general, researches tend to focus more on managerial actions and less on theories concerning dimensions, antecedents and consequences of Consumer-Brand Experience. In this regard, some effort has been made to understand and conceptualize Consumer-Brand Experience and to define its relationship with others variables but there is no consensus yet about the term, construct and definition.

Moreover, even if prior studies offer important insight about Consumer-Brand Experience and its related constructs, present research should fill some important gaps in this scholarly inquiry. In other words, research has not accurately examined the stage at which the Consumer-Brand Experience concept stands and in which direction it is moving.

First, whilst much research recognizes the importance of the experience in interacting with a brand, there is little attempt to show the factors that affect brand experience and relate CBEx with other constructs. Second, until now the literature has mostly focused on the concepts of brand equity, brand loyalty, and brand trust but less on the concept of experience. As pointed out by Palmer (2010), in order to have a clear idea of this construct, systematic and in-depth assessments are required. Moreover, this study tries to answer Lemon and Verhoef's (2016, p. 74) call that states "To date, no research has clearly shown the nomological network of customer experience and how this construct relates to other customer-focused constructs." So far, studies have stressed the necessity to understand the effects and the factors that shape CBEx but a comprehensive Consumer-Brand Experience model remains underdeveloped.

Thus, to the best of our knowledge, only a limited number of studies explore the concept of experience in depth from a theoretical perspective.

The scarcity of systematic scholarly research on the experience construct in marketing literature calls urgently for a theory-based conceptual framework that can provide stimuli and operates as groundwork for future research.

This study attempts to offer a threefold contribution. First, this article reviews the main findings of the consumer and brand experience literature, providing a systematization of the literature of the Consumer-Brand Experience construct covering 35 years. Thus, the present study aims to develop a significant conceptualization of the growth, theorization and management of Consumer-Brand Experience by doing a systematic review on the above-mentioned topic. Second, the present paper tries to satisfy the need of a unified conceptual model of CBEx on the basis of current literature. Third, this study provides a research agenda for future research.

To sum up, this study addresses the following research questions:

RQ1: What is the state of the art of the CBEx concept?

RQ1a: What are the dimensions that shape the CBEx?

RQ1b: How does CBEx impact on consumer behavior? 


\section{Methodology}

This study adopted the systematic method for the literature review (Cook et al., 1997; Denyer \& Tranfield, 2008; Tranfield et al., 2003) as it is arguably the most efficient, reliable and high-quality method for examining extensive bases of literature (Denyer \& Tranfield, 2009). Systematic reviews "summarize in an explicit way, what is known and not known about a specific practice related question" (Briner et al., 2009). On the other hand, traditional narrative reviews generally lack thoroughness, are unable to accurately comprehend and interpret the findings of multiple studies (Popay et al., 2006; Tranfield et al., 2003), and are also limited in scope due to lack of objectivity in approach (Keränen et al., 2012). The systematic method, instead, aims to collect and link together as many existing relevant studies as possible by adopting a structured and systematic process of reviewing the literature (Callahan, 2014).

The basic principles behind adopting a systematic review method are (Thorpe et al., 2005):

- transparency;

- clarity;

- focus;

- unifies research and practitioner communities;

- equality;

- accessibility;

- broad coverage;

- synthesis.

Thus, consistent with previous researches that have used this methodology, this systematic review followed six stages. The first step of the study involved the delineation of the field of research, the choice of the keywords and the databases. Moreover, inclusion and exclusion criteria were established. The research string was developed through the previous knowledge on all marketing experience literature so that no keyword related to customer and brand experience was left out. This study has no time restrictions and presents a review of published research articles on consumer and brand experience in academic journals since its inception.

The review comprises English-language peer-reviewed journal articles only. "EBSCO Host - Business Source Complete" was used as the first database and abstracts as the target. The substantive relevance of the articles focusing on consumer and brand experience was safeguarded by ensuring all the selected articles contained the following keywords: "brand experience" OR "customer experience" OR "consumer experience" OR "experience marketing" OR "customer experience management" OR "experience branding" OR "service experience" OR "consumption experience" OR "product experience". The selection of the EBSCO database was due to its wider coverage of journals. This yielded 595 papers. Additionally, the same search was run in Scopus, another highly-used database to ensure that no important researches on this topic were excluded.

A last check with the same search was made on Google Scholar in order to ensure the best data collection.

After integrating and eliminating duplicate documents, a total of 945 papers were initially identified. The last search was performed in September 2018.

As mentioned above, consistent with several recent systematic assessments of the management literature (Newbert, 2007; Pittaway et al., 2004; Thorpe et al., 2005), a set of criteria was established for step-by-step screening of the papers found (see Table 1).

Table 1. Inclusion and exclusion criteria

\begin{tabular}{ll}
\hline INCLUSION & EXCLUSION \\
\hline Published academic journal articles & Books, conference proceedings, editorials, viewpoints, newspaper \\
Full text available & articles, working papers \\
English articles & Full text unavailable \\
Studies in marketing and psychology focusing on & Non-English articles \\
Consumer/Customer or Brand Experience & Studies mainly focused on engineering or medical issues \\
Studies mainly focused on B2C experience & Studies mainly focused on B2B experience \\
\hline
\end{tabular}


The selection process followed a step-by-step research protocol (Table 2), which is consistent with the previous research (Newbert, 2007; Thorpe et al., 2005).

Thus, the following step was to select a list of pertinent articles by a preliminary extensive reading of all the abstracts to ensure substantive context. As a result, the number of papers discharged in this preliminary screening was significant and only 153 papers were kept for the subsequent steps. Similar drops in numbers are common in systematic literature reviews (Newbert, 2007; Pittaway et al., 2004) and, in this case, it is attributed to ensuring coherence and conformity with the research objectives.

The fifth step was to read every selected article in full. Finally, references of studies were checked to make sure no study was left without review, so a "snowballing" technique was adopted to support the results from the previous phases. This ensured reliability of the research process. After all these stages, the final number of articles analyzed was 107.

Table 2. Summary of the results

\begin{tabular}{lll}
\hline Step & Description & Total articles \\
\hline & Articles retrieved from EBSCO, Scopus and Google Scholar (after the elimination of & 945 \\
$\mathbf{3}$ & duplicate papers) & 153 \\
$\mathbf{4}$ & All the articles where abstracts are substantively relevant & 104 \\
$\mathbf{5}$ & Articles whose text was relevant & 107 \\
$\mathbf{6}$ & Snowballing technique & \\
\hline
\end{tabular}

Source: Elaboration on the dataset.

The articles, consistent with recent systematic literature reviews, were thoroughly studied and analyzed in a qualitative fashion (Barclay et al., 2011; Pittaway \& Cope, 2007). Moreover, the content analysis of text was done manually and a data extraction form was used to summarize critical data, such as key findings and methodological features. The articles were also analyzed in terms of context, purpose, conceptualization, dimensions, relationships, research design, findings, implications and contributions. An Excel dataset was set up to collect all the qualitative information on the selected papers. Such a procedure allowed the researcher to investigate evolutionary trends and topics of interest through the use of ad hoc pivot tables. This enabled the researcher to identify quickly the overall nature of the existing research, its epistemological assumptions and methodological features.

\section{Findings}

\subsection{Trends of CBEx}

This section shows the findings from the 107 relevant articles from which discussion and managerial implications expressed in the next sections are drawn.

Some statistics on the time period and journal distribution are provided too. Fig. 1 lists the temporal trends of the articles. One can see a consistent interest in the researched topic during the time period.

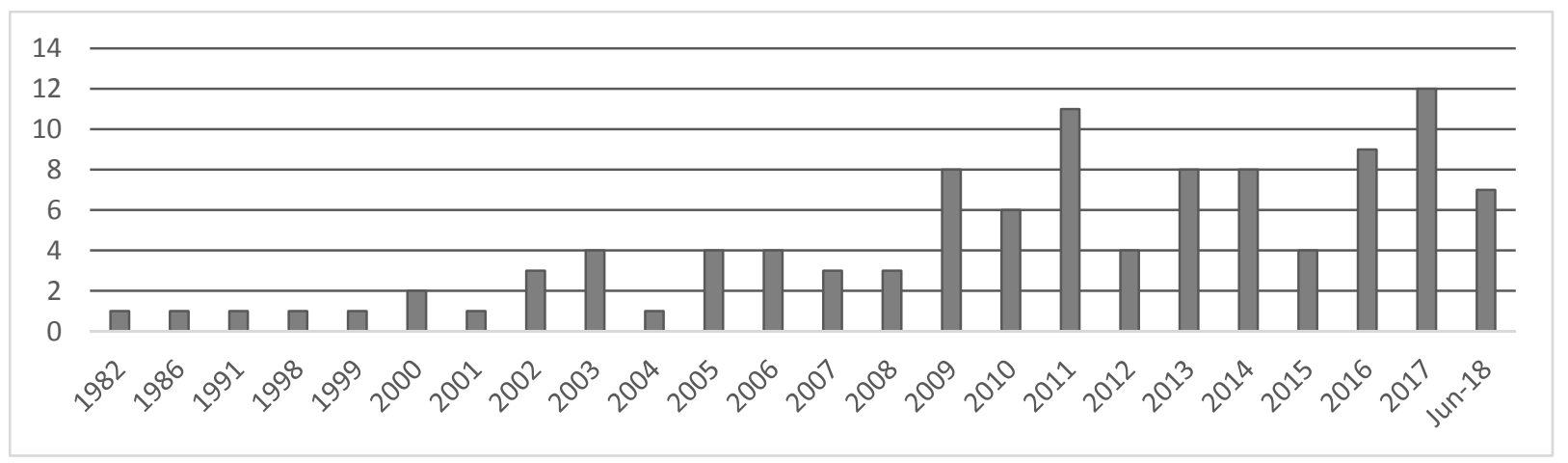

Source: Elaboration on the dataset.

Figure 1. Temporal trends of the articles 
Studies on experience in marketing literature were initiated by Holbrook and Hirschman in 1982. While the concept of "brand experience" appears for the first time in 1991 with Ortmeyer and Huber, it was thoroughly defined and measured by Brakus et al. in 2009. Until this year the studies on brand and consumer experience were few and fragmented, even though by 2005 researchers had started explaining the experience concept in depth and from various points of view (Chattopadhyay \& Laborie, 2005; Ha \& Perks, 2005; Pettit, 2005). During that year the first paper on digital experience was published (Ha \& Perks, 2005).

Over these years, CBEx has been defined by various authors and there is also a fragmentation among the different journals that have focused on experience in the marketing field.

Table 3 categorizes the overall population per academic journal. Results show that the works within the dataset are published in 53 different international journals.

Table 3. List of journals and distributions of articles

\begin{tabular}{|c|c|c|c|}
\hline$\#$ & Journal & Number of Studies & $\%(J)$ \\
\hline 1 & Journal of Brand Management & 16 & 14.95 \\
\hline 2 & Journal of Marketing Management & 7 & 6.54 \\
\hline 3 & International Journal of Market Research & 5 & 4.67 \\
\hline 4 & Journal of Business Research & 4 & 3.74 \\
\hline 5 & Journal of Consumer Research & 4 & 3.74 \\
\hline 6 & Journal of Product and Brand Management & 4 & 3.74 \\
\hline 7 & Advances in Consumer Research & 3 & 2.80 \\
\hline 8 & Journal of Consumer Behaviour & 3 & 2.80 \\
\hline 9 & Journal of Marketing & 3 & 2.80 \\
\hline 10 & Journal of Marketing \& Communication & 3 & 2.80 \\
\hline 11 & Journal of Services Research & 3 & 2.80 \\
\hline 12 & CLEAR International Journal of Research in Commerce \& Management & 2 & 1.87 \\
\hline 13 & IUP Journal of Brand Management & 2 & 1.87 \\
\hline 14 & Journal of Advertising Research & 2 & 1.87 \\
\hline 15 & Journal of Retailing & 2 & 1.87 \\
\hline 16 & Journal of Retailing and Consumer Services & 2 & 1.87 \\
\hline 17 & Journal of Strategic Marketing & 2 & 1.87 \\
\hline 18 & Journal of the Academy of Marketing Science & 2 & 1.87 \\
\hline 19 & Marketing Theory & 2 & 1.87 \\
\hline 20 & Service Industries Journal & 2 & 1.87 \\
\hline 21 & Academy of Marketing Studies Journal & 2 & 1.87 \\
\hline 22 & California Management Review & 1 & 0.93 \\
\hline 23 & Entrepreneurial Executive & 1 & 0.93 \\
\hline 24 & European Business Review & 1 & 0.93 \\
\hline 25 & European Management Journal & 1 & 0.93 \\
\hline 26 & Foundations and Trends in Marketing & 1 & 0.93 \\
\hline 27 & Global Business Review & 1 & 0.93 \\
\hline 28 & Harvard Business Review & 1 & 0.93 \\
\hline 29 & International Business Management & 1 & 0.93 \\
\hline 30 & International Journal of Business \& Information & 1 & 0.93 \\
\hline 31 & International Journal of Contemporary Hospitality Management & 1 & 0.93 \\
\hline 32 & International Journal of Hospitality Management & 1 & 0.93 \\
\hline 33 & International Journal of Management Reviews & 1 & 0.93 \\
\hline 34 & Journal of Advertising & 1 & 0.93 \\
\hline 35 & Journal of Consumer Marketing & 1 & 0.93 \\
\hline 36 & Journal of Consumer Psychology & 1 & 0.93 \\
\hline 37 & Journal of Customer Behaviour & 1 & 0.93 \\
\hline 38 & Journal of Hospitality Marketing \& Management, & 1 & 0.93 \\
\hline 39 & Journal of Marketing Communications & 1 & 0.93 \\
\hline 40 & Journal of Relationship Marketing & 1 & 0.93 \\
\hline 41 & Journal of Service Theory and Practice & 1 & 0.93 \\
\hline 42 & Journal of Services Marketing & 1 & 0.93 \\
\hline 43 & Management Decision & 1 & 0.93 \\
\hline 44 & Management Review & 1 & 0.93 \\
\hline 45 & Marketing Letters & 1 & 0.93 \\
\hline
\end{tabular}




\begin{tabular}{|c|c|c|c|}
\hline 46 & Marketing Management & 1 & 0.93 \\
\hline 47 & Marketing Research & 1 & 0.93 \\
\hline 48 & Marketing Science & 1 & 0.93 \\
\hline 49 & MIT Sloan Management Review & 1 & 0.93 \\
\hline 50 & Psychology \& Marketing & 1 & 0.93 \\
\hline 51 & Research in Economics \& Business: Central \& Eastern Europe & 1 & 0.93 \\
\hline 52 & Review of Marketing Research & 1 & 0.93 \\
\hline \multirow[t]{2}{*}{53} & Studies in Business \& Economics & 1 & 0.93 \\
\hline & Total & 107 & $100 \%$ \\
\hline
\end{tabular}

Source: Elaboration on the dataset.

The major contributions come from Journal of Brand Management, Journal of Marketing Management and by journals focused on consumer behavior (such as Journal of Consumer Research, Consumer Behaviour and Advances in Consumer Research).

Moreover, $77 \%$ of the papers are empirical studies (in particular $66 \%$ have a quantitative research design and $11 \%$ have a qualitative research design) and the remaining $33 \%$ are conceptual studies.

With regard to the notion of experience, it has appeared in the marketing literature in many ways. Table 4 illustrates the different names used to define the experience concept.

Table 4. Experience' constructs, authors and definitions

\begin{tabular}{|c|c|c|c|}
\hline $\begin{array}{l}\text { Type of } \\
\text { Construct }\end{array}$ & $\begin{array}{l}\text { Number of } \\
\text { studies }\end{array}$ & Authors & Main Definitions \\
\hline $\begin{array}{l}\text { Customer } \\
\text { experience }\end{array}$ & 37 & $\begin{array}{l}\text { Carbone, 1998; Novak et al., 2000; Berry et al., } \\
\text { 2002; Cole-Colander, 2003; Haeckel et al., 2003; } \\
\text { Frow \& Payne, 2007; Gentile et al., 2007; Ryder, } \\
\text { 2007; Patterson et al., 2008; Jain \& Bagdare, 2009; } \\
\text { Tynan \& McKechnie, 2009; Verhoef et al., 2009; } \\
\text { Chang \& Horng, 2010; Palmer, 2010; Chakravorti, } \\
\text { 2011; Ismail, 2011; Maklan \& Klause, 2011; } \\
\text { Lemke et al., 2011; Walls et al., 2011; Nambisan } \\
\text { \& Watt, 2011; Dumitrescu et al., 2012; Klaus \& } \\
\text { Maklan, 2013; Popa \& Barna, 2013; Rawson et al., } \\
\text { 2013; Sharma \& Chaubey, 2014; Chahal et al., } \\
\text { 2015; Bhandari, 2016; Hwang \& Seo, 2016; } \\
\text { Lemon \& Verhoef, 2016; Stein \& Ramaseshan, } \\
\text { 2016; Sharma et al., 2016; Brun et al., 2017; } \\
\text { Manhas \& Chauhan, 2017; Homburg et al., 2017; } \\
\text { Jain et al., 2017; Maklan et al., 2017; Shobeiri et } \\
\text { al., 2018. }\end{array}$ & $\begin{array}{l}\text { "The Customer Experience originates from a set of interactions } \\
\text { between a customer and a product, a company, or part of its } \\
\text { organization, which provoke a reaction. This experience is } \\
\text { strictly personal and implies the customer's involvement at } \\
\text { different levels (rational, emotional, sensorial, physical, and } \\
\text { spiritual). Its evaluation depends on the comparison between a } \\
\text { customer's expectations and the stimuli coming from the } \\
\text { interaction with the company and its offering in correspondence } \\
\text { of the different moments of contact or touch-points" (Gentile et } \\
\text { al., 2007). } \\
\text { "Customer experience is the aggregate of feelings, perceptions } \\
\text { and attitudes formed during the entire process of decision } \\
\text { making and consumption chain involving an integrated series of } \\
\text { interaction with people, objects, processes and environment, } \\
\text { leading to cognitive, emotional, sensorial and behavioural } \\
\text { responses" (Jain et al., 2017). }\end{array}$ \\
\hline $\begin{array}{l}\text { Brand } \\
\text { experience }\end{array}$ & 30 & $\begin{array}{l}\text { Ortmeyer \& Huber, 1991; Andrew, 2003; } \\
\text { Chattopadhyay \& Laborie, 2005; Pettit, 2005; } \\
\text { Alloza, 2008; Barnham, 2008; Atwal \& Williams, } \\
\text { 2009; Brakus et al., 2009; Schmitt, 2009; } \\
\text { Zarantonello \& Schmitt, 2010; Hultén, 2011; } \\
\text { Iglesias et al., 2011; Jung \& Soo, 2012; Lundqvist } \\
\text { et al., 2013; Nysveen et al., 2013; Nysveen \& } \\
\text { Pedersen, 2014; Cleff et al., 2014; Başer et al., } \\
\text { 2015; Nejad et al., 2015; Khan \& Rahman, 2015; } \\
\text { Schmitt et al., 2015; Hepola et al., 2017; Huang, } \\
\text { 2017; Khan \& Fatma, 2017; Saari \& Mäkinen, } \\
\text { 2017; Andreini et al., 2018; de Oliveira Santini et } \\
\text { al., 2018; Ong et al., 2018; van der Westhuizen, } \\
\text { 2018; Wiedmann et al., 2018. }\end{array}$ & $\begin{array}{l}\text { "The perception of the consumers, at every moment of contact } \\
\text { they have with the brand, whether it is in the brand images } \\
\text { projected in advertising, during the first personal contact, or the } \\
\text { level of quality concerning the personal treatment they receive" } \\
\text { (Alloza, 2008). } \\
\text { "Subjective, internal consumer responses (sensations, feelings, } \\
\text { and cognitions) and behavioral responses evoked by } \\
\text { brand-related stimuli that are part of a brand's design and } \\
\text { identity, packaging, communications, and environments" } \\
\text { (Brakus et al., 2009). }\end{array}$ \\
\hline $\begin{array}{l}\text { Consumpti } \\
\text { on } \\
\text { experience }\end{array}$ & 12 & $\begin{array}{l}\text { Holbrook \& Hirschman, 1982; Havlena \& } \\
\text { Holbrook, 1986; Addis \& Holbrook, 2001; Carù \& } \\
\text { Cova, 2003; Novak et al., 2003; Holbrook, 2006; } \\
\text { Tynan \& McKechnie, 2009; Schmitt, 2011; } \\
\text { Roederer, 2012; Minkiewicz et al., 2014; Lanier \& } \\
\text { Rader, 2015; Chun et al., 2017. }\end{array}$ & $\begin{array}{l}\text { "Consumption has begun to be seen as involving a steady flow } \\
\text { of fantasies, feelings, and fun encompassed by what we call the } \\
\text { "experiential view". This experiential perspective is } \\
\text { phenomenological in spirit and regards consumption as a } \\
\text { primarily subjective state of consciousness with a variety of } \\
\text { symbolic meanings, hedonic responses, and esthetic criteria" } \\
\text { (Holbrook \& Hirschman, 1982). }\end{array}$ \\
\hline
\end{tabular}




Consumer $9 \quad$ Schmitt, 1999; Harris et al., 2000; O'Cass \& "Five different types of experiences, or strategic experiential

experience Grace, 2004; Long-Tolbert et al., 2006; Bettingen modules (SEMs), that

\& Luedicke, 2009; Janiszewski, 2010; Schmitt \&

Zarantonello, 2013; Riivits-Arkonsuo et al., 2014;

Söderlund \& Sagfossen, 2017; Yang et al., 2017.

Marketers can create for customers are distinguished: sensory experiences (SENSE); affective experiences (FEEL); creative cognitive experiences (THINK); physical experiences, behaviours and lifestyles (ACT); and social-identity experiences that result from relating to a reference group or culture (RELATE). These experiences are implemented through so-called experience providers (ExPros) such as communications, visual and verbal identity, product presence, electronic media, etc." (Schmitt, 1999).

\begin{tabular}{|c|c|c|c|}
\hline $\begin{array}{l}\text { Service } \\
\text { experience }\end{array}$ & 4 & $\begin{array}{l}\text { Bonnin, 2006; Helkkula \& Kelleher, 2010; } \\
\text { Beltagui et al., 2015; Wall-Mullen \& Envick, } \\
2015 .\end{array}$ & $\begin{array}{l}\text { "Customer service experience (..) is understood as a holistic } \\
\text { phenomenon, which is subjective, event specific, personal and } \\
\text { individually and socially-constructed" (Helkkula \& Kelleher, } \\
2010) .\end{array}$ \\
\hline $\begin{array}{l}\text { Online } \\
\text { brand } \\
\text { experience }\end{array}$ & 5 & $\begin{array}{l}\text { Ha \& Perks, 2005; Chen, 2012; Morgan-Thomas } \\
\& \text { Veloutsou, 2013; Jafari et al., 2016; Cleff et al., } \\
2018 .\end{array}$ & $\begin{array}{l}\text { "Brand experience as a consumer's positive navigations (ie using } \\
\text { web-based communities and participating in events) and } \\
\text { perceptions (ie the attractiveness of cookies, variety and } \\
\text { uniqueness of visual displays and value for money) with a } \\
\text { specific website" (Ha \& Perks, 2005). }\end{array}$ \\
\hline $\begin{array}{l}\text { Online } \\
\text { customer } \\
\text { experience }\end{array}$ & 5 & $\begin{array}{l}\text { Rose et al., 2010; Ishida \& Taylor, 2012; Rose et } \\
\text { al., 2012; Klaus \& Nguyen, 2013; Song, } 2015 .\end{array}$ & $\begin{array}{l}\text { "We assume OCE to be a psychological state manifested as a } \\
\text { subjective response to the e-retailer's website. } \\
\text { The customer engages in cognitive and affective processing of } \\
\text { incoming sensory information from the website, the result of } \\
\text { which is the formation of an impression in memory" (Rose et al., } \\
2012 \text { ). }\end{array}$ \\
\hline $\begin{array}{l}\text { Retail } \\
\text { experience }\end{array}$ & 3 & Ishida \& Taylor, 2012; Bagdare, 2013, 2016. & $\begin{array}{l}\text { "Retail customer experience has all the elements that encourage } \\
\text { or inhibit customers during their contact with a retailer" } \\
\text { (Bagdare, 2013). }\end{array}$ \\
\hline $\begin{array}{l}\text { Product } \\
\text { experience }\end{array}$ & 2 & Hoch, 2002; Daugherty, et al. 2008. & $\begin{array}{l}\text { "Product experience seduces consumers into believing that they } \\
\text { learn more than is actually so (..) Product experience often } \\
\text { proceeds like a seduction (..) The engaging aspects of experience } \\
\text { catch the consumer's attention" (Hoch, 2002). }\end{array}$ \\
\hline
\end{tabular}

Source: Elaboration on the dataset.

Findings suggest that there is no agreement regarding the label, the definition, the different dimensions of the constructs and the behavioral outcomes.

\subsection{Dimensions and features of CBEx}

There are various dimensions that make up experience concepts. Table 5 shows that constructs and definitions vary in breadth and focus. Some of the definitions are explicit in their conceptualization and in underlying specific dimensions, whereas others are more generic and comprehensive. With respect to dimensionality, 4 of the 9 above definitions of experience identify what kind of response the experience elicits.

Table 5. Underlying experience dimensions in literature definitions

\begin{tabular}{|c|c|c|}
\hline Construct & Dimensions & Authors \\
\hline Consumption Experience & $\begin{array}{l}\text { Cognitive, Behavioral, Affective, Praxeological, } \\
\text { Hedonico-Sensorial, Rethoric, Relationship with } \\
\text { time. }\end{array}$ & $\begin{array}{l}\text { Holbrook \& Hirschmann, 1982; Roederer, } \\
2012 .\end{array}$ \\
\hline Customer/Consumer Experience & $\begin{array}{l}\text { Hedonic, Personal Progression, Social Interaction, } \\
\text { Efficiency, Surreal Feelings, Rational, Emotional, } \\
\text { Sensorial, Physical, Spiritual, Cognitive. }\end{array}$ & $\begin{array}{l}\text { Schmitt, 1999; Gentile et al., 2007; } \\
\text { Verhoef et al., 2009; Maklan \& Klaus, } \\
\text { 2011; Popa \& Barna, 2013; Bagdara, } 2016 .\end{array}$ \\
\hline Brand Experience & $\begin{array}{l}\text { Sensorial, Affective, Behavioral, Intellectual, } \\
\text { Cognitive, Emotional, Relational. }\end{array}$ & $\begin{array}{l}\text { Ha \& Perks, 2005; Brakus et al., 2009; Jung } \\
\& \text { Soo, 2012; Cleff et al., } 2014 .\end{array}$ \\
\hline Online Experience & $\begin{array}{l}\text { Emotional, Behavioral, Affective, Cognitive, } \\
\text { Sensorial, Psychological. }\end{array}$ & $\begin{array}{l}\text { Rose et al., 2010; Morgan-Thomas } \\
\text { \&Veloutsou, 2013. }\end{array}$ \\
\hline
\end{tabular}

Source: Elaboration on the dataset. 


\subsection{Antecedents and consequences of CBEx}

The review of the literature shows a very heterogeneous scenario regarding the relationships between CBEx and the other constructs. Until now, studies on antecedents and outcomes on CBEx have focused on specific settings or industries, such as: services and food services context (Beltagui et al., 2016; Helkkula \& Kelleher, 2010; Khan \& Fatma, 2017; Wall-Mullen \& Envick, 2015), retail context (Bagdare, 2013, 2016; Ishida \& Taylor, 2012), online context (Chen, 2012; Ha \& Perks, 2005; Morgan-Thomas \& Veloutsou, 2013; Rose et al., 2010), and tourism industry (Maklan \& Klaus, 2011; Ong et al., 2018).

A shared and unified model is difficult to achieve especially because constructs, such as brand trust, seem to be an antecedent in some studies and an outcome in others (Lemon \& Verhoef, 2016); probably its relation with CBEx depends on the reference context.

Literature has come to agree that the strength of the Consumer-Brand Experience influences consumers' ability to draw inferences about the brand personality and influences brand satisfaction and loyalty (Brakus et al., 2009). Scholars also recognize that a favorable Consumer-Brand Experience positively affects marketing and consumer behavior outcomes. In particular, satisfaction and loyalty of a brand play an important role in predicting future intentions. At the same time studies have mainly focused on factors such as satisfaction and loyalty but have not considered the drivers of CBEx as a broad construct.

Experiential outcomes have broadly been explained as a combination of cognitive, emotional, behavioral and sensorial responses by the consumer, however, hedonic and emotional benefits have been reported to play a more dominant role in shaping customers' experiences (Babin et al., 1994; Carpenter \& Moore, 2009; Jones et al., 2006).

Table 6 provides an overview and a classification of antecedents and outcomes that have been investigated in previous studies.

Table 6. Antecedents and outcomes of the experience construct

\begin{tabular}{|c|c|c|}
\hline \multicolumn{3}{|c|}{ Antecedents } \\
\hline Key supporting literature & Experience Construct & Constructs \\
\hline Mascarenhas et al., 2006 & Customer Experience & $\begin{array}{l}\text { Anticipation and fulfilment of customer needs and wants, } \\
\text { Provision of real consumer experiences, Provision of real } \\
\text { emotional experiences, Experiences as distinct market offering, } \\
\text { Experiences as interactions, Experiences as engaging memories }\end{array}$ \\
\hline Verhoef et al., 2009 & Customer Experience & $\begin{array}{l}\text { Customer-brand perception, Social environment, Service } \\
\text { interface, Retail atmosphere, Assortment, Price, Customer } \\
\text { experiences in alternative channels, Retail brand, Past customer } \\
\text { experience }\end{array}$ \\
\hline Palmer, 2010 & Customer Experience & $\begin{array}{l}\text { Tangible and process quality, Brand relationships, Interpersonal } \\
\text { relationships, Sequencing of clues and relationships, Effects of } \\
\text { emotions on encoding, Perceptual distortion over time, attitude }\end{array}$ \\
\hline Rose et al., 2010 & Online Customer Experience & $\begin{array}{l}\text { Perceived usefulness, Perceived benefits, Perceived control, } \\
\text { Skill, Trust propensity, Perceived risk, Enjoyment }\end{array}$ \\
\hline Maklan \& Klaus, 2011 & Customer Experience Quality & $\begin{array}{l}\text { Peace of mind, Outcomes focus, Moment of truth, Product } \\
\text { experience }\end{array}$ \\
\hline Ismail, 2011 & $\begin{array}{l}\text { Customer Experience } \\
\text { (services) }\end{array}$ & $\begin{array}{l}\text { Advertising, price, Employees, Service scape, Core service, } \\
\text { WOM, Mood, Perceived service quality }\end{array}$ \\
\hline Kim et al., 2011 & Service Experience & $\begin{array}{l}\text { Environment, Benefits, Convenience, Accessibility, Utility } \\
\text { Incentive, Trust }\end{array}$ \\
\hline Lemke et al., 2011 & Customer Experience & $\begin{array}{l}\text { Communication Encounter (Communication, Relationship with } \\
\text { company), Service Encounter (Service Quality, Product Quality, } \\
\text { Network Quality), Usage Encounter (Relationship with other } \\
\text { customers, Social impact) }\end{array}$ \\
\hline Morgan-Thomas \& Veloutsou, 2013 & $\begin{array}{l}\text { Online Brand } \\
\text { Experience }\end{array}$ & $\begin{array}{l}\text { Perceived ease of use, Perceived usefulness, Brand Reputation, } \\
\text { Brand trust }\end{array}$ \\
\hline Bagdare, 2013 & Retail Experience & Joy, Mood, Leisure, Distinctive \\
\hline Lemon \& Verhoef, 2016 & Customer Experience & $\begin{array}{l}\text { Engagement (as a part of overall CE), Point of touch, Service } \\
\text { quality attributes, Price image, Loyalty programs, External } \\
\text { environment }\end{array}$ \\
\hline Khan \& Fatma, 2017 & Brand Experience & Marketing communication, Brand clues, Event marketing \\
\hline
\end{tabular}




\begin{tabular}{|c|c|c|}
\hline \multicolumn{3}{|c|}{ Outcomes } \\
\hline Construct & Experience Construct & Constructs \\
\hline Grace \& O'Cass, 2004 & Service Experience & Satisfaction, Brand Attitude \\
\hline Ha \& Perks, 2005 & $\begin{array}{l}\text { Online Brand } \\
\text { Experience }\end{array}$ & Familiarity, Satisfaction, Brand Trust \\
\hline Brakus et al., 2009 & Brand Experience & Brand Personality, Loyalty, Satisfaction \\
\hline Biedenbach \& Marell, 2009 & Customer Experience & Brand Equity \\
\hline Rose et al., 2010 & Online Customer Experience & Customer Satisfaction, Re-purchase Intentions \\
\hline Iglesias et al., 2011 & Brand Experience & Brand Loyalty, Affective Commitment \\
\hline Lemke et al., 2011 & Customer Experience & Commitment, Purchase, Retention, WOM \\
\hline Lemon \& Verhoef 2016 & Customer Experience & $\begin{array}{l}\text { Customer satisfaction, Trust, Commitment, Engagement (as a } \\
\text { part of overall CE). }\end{array}$ \\
\hline Morgan-Thomas \& Veloutsou, 2013 & $\begin{array}{l}\text { Online Brand } \\
\text { Experience }\end{array}$ & Behavioral intentions, Satisfaction, Online Brand Relationships \\
\hline Maklan \& Klaus, 2011 & Customer Experience Quality & Loyalty, WOM, Satisfaction \\
\hline Ismail, 2011 & $\begin{array}{l}\text { Customer Experience } \\
\text { (services) }\end{array}$ & Brand Loyalty \\
\hline Khan \& Fatma, 2017 & Brand Experience & $\begin{array}{l}\text { Brand Trust, Purchase Brand Loyalty, Attitudinal Brand Loyalty, } \\
\text { Customer Satisfaction, WOM, Brand Credibility, Brand Attitude }\end{array}$ \\
\hline de Oliveira Santini et al., 2018 & Brand Experience & Brand Satisfaction, Brand Trust, Brand Loyalty, WOM \\
\hline
\end{tabular}

\section{Discussion}

The concept of experience in marketing literature is not new but it is fragmented and still open. In particular, the most crucial matter is the necessity to keep in mind that the service or product or online experiences are only a little part of the overall process while the CBEx embraces all the emotional and psychological aspects of the interactions between a brand and a consumer. Thus, literature until now has failed to focus on a broadest construct, focusing mainly on small parts of the whole experience system.

In addition, most studies identify experiences as not only emotional responses and undertake a holistic approach by identifying affective, cognitive, behavioral and psychological processes. Hence, multidimensionality is expressed in several formal definitions (Brakus et al., 2009; Gentile et al., 2007; Lemon \& Verhoef, 2016), Thus, CBEx is a coalescence of significant meaning with combined behaviors, thoughts and the "three Fs" of fantasies, feelings and fun that occur during the consumption (Holbrook \& Hirschman, 1982). Along these lines, experience with a brand has more impact than product features and benefits. As a result, modern consumers that are rational as well as emotional buy products and services not only on the basis of their functional and utilitarian benefits (Schmitt, 1999; Schmitt \& Rogers, 2008) but also to obtain satisfying experiences from consumption (Morrison \& Crane, 2007; Pine \& Gilmore, 1998.). Thus, a meaningful experience can produce a deeper meaning and be more memorable, which can affect many constructs of consumer behavior, such as: repurchase intention, engagement, satisfaction, loyalty, commitment, the willingness to pay a premium price and the word-of-mouth (WOM) about the brand (Brakus et al., 2009; Hoch, 2002; Islam \& Rahman, 2016; Lemon \& Verhoef, 2016; Rose et al., 2010; Schmitt, 1999).

After the analysis of the findings, five main dimensions of Consumer-Brand Experience have arisen:

1) Multi-dimensional

2) Subjective

3) Holistic

4) Co-created

5) Systemic

Boundaries are permeable and dimensions intersected and intertwined among them. Fig. 2 represents these 5 characteristic of CBEx. 


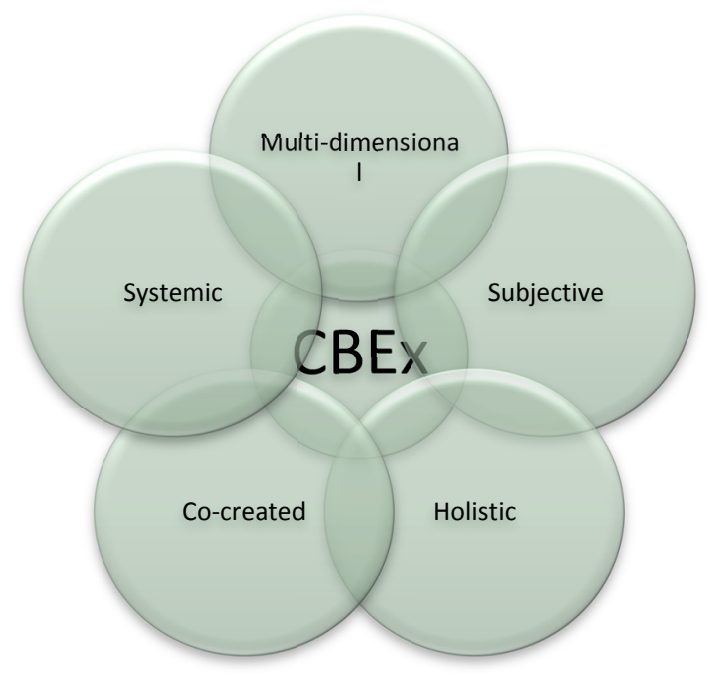

Figure 2. The CBEx "flower"

\subsection{CBEx Is Multi-Dimensional}

The current literature states that CBEx is a polyhedric construct focusing on various consumers' responses to a firm's offerings during the entire decision-making process. Scholars have come to agree that the CBEx is multi-dimensional in nature involving cognitive, emotional, behavioral, sensorial, social, and spiritual responses to all interactions with a firm (Bolton et al., 2014; Gentile et al., 2007; Lemke et al., 2011; Lemon \& Verhoef, 2016; Schmitt, 1999, 2011; Verhoef et al., 2009). Thus, CBEx includes a combination of sensing, feeling, thinking (rationally as well as irrationally), acting (interacting with the environment through physical actions) and, in a social context, relating to others individuals through the brand (Brakus et al., 2009; Fournier, 1998; McAlexander et al., 2002; Schmitt, 1999; Schmitt et al., 2015). To be precise, Schmitt (1999) was the first to explain the concept of brand experience from a multi-dimensional point of view, specifically cognitive, sensory, affective, behavioral and social. Along the same lines, Gentile and colleagues (2007) find evidence of six components of customer experience. These are defined as: sensorial, emotional, cognitive, pragmatic, lifestyle, and relational. While, Brakus et al. (2009) have conceptualized experiences as multi-dimensional, including sensory, affective-cognitive, and behavioral dimensions. The two psychological constructs of cognition and affect have been consistently identified as influential components of consumer behavior and consumer experience (Bagozzi et al., 1999; Frow \& Payne, 2007; Tynan \& McKechnie, 2009) and are incorporated in models of consumer and brand experience.

\subsection{CBEx Is Subjective}

Findings reveal that CBEx can be conceptualized as a psychological construct, which is a holistic, subjective response resulting from consumer interactions with the brand and which may involve different levels of involvement (Gentile et al., 2007; Lemke et al., 2011).

The characteristic of "non-linearity" of the CBEx has emerged from the review. This school of thought is made by the fact that two similar stimuli should be perceived as very different from two different consumers. It has been noted that perception fluctuates between individuals, and for any individual and any fluctuations may be related to situational factors. Impression formation is highly personal, being based on the individual's interpretation of incoming sensory data from the external environment (Carbone \& Haeckel, 1994).

Regarding this argument, Sheth et al. (1999) identified a combination of three factors that help shape a consumer's attitude to experience. Firstly, stimulus characteristics; individuals should perceive a stimulus differently in relation to their sensory characteristics and information. The second element is the context; in perceiving stimuli, individuals are also affected by the context they live in. Finally, the situational factors; in fact, information received includes prior experiences that are filtered by social, cultural and personal characteristics. Thus, the experience is strictly personal and implies the customer's involvement at different levels; the experience is conditioned by differences between individuals, differences over time in an individual's emotional state, and a variety of situation-specific factors. 
Thus, the role of emotions that has a positive affective outcome for one consumer may have a negative outcome for another consumer with a different emotional predisposition (Oliver, 1999; Palmer, 2010).

Accordingly, it can be concluded that every experience is a reflection of internal, subjective and unique mental processing by a consumer.

\subsection{CBEx Is Holistic}

CBEx can be viewed as an umbrella construct (Kranzbühler et al., 2018) defined as a broad concept used to embrace all the stages of consumer decision making and consumption process.

Gronroos (2006) states that "customer value is not created by one element alone, but by the total experience of all elements."

Therefore, a Consumer-Brand Experience may relate to specific aspects of the offering, such as online brand experience (Morgan-Thomas \& Veloutsou, 2013; Rose et al., 2010, 2012) or service experience (Kim et al., 2011; Verhoef et al., 2009) and it consists of individual contacts between the firm and the customer at distinct points in the experience (the so called "touchpoints"). At these touchpoints with consumers, brands provide multiple stimulations through sight, sound, smell, touch, and taste. Meanwhile, when consumers have an experience with a brand, they collect various stimuli of a brand (logo, brand characteristics, jingles, etc.). In perceiving most brands, however, more than one sense is involved and mostly, at the moment of consumption, brands involve all five senses (Schmitt, 1999).

The overall experience between a brand and a consumer is also created through a collection of these touchpoints in multiple phases of a customer's decision-making process, multiple times and in multiple spaces (both online and offline).

In fact, consumers interact and experience with a brand over time: at the very beginning during the information search, successively during the purchase, then with the response and the consumption, and finally during the evaluation post consumption; in other words, during the entire buying decision process (Arnould et al., 2002; Chang \& Chieng, 2006; Schmitt, 1999; Schmitt \& Rogers, 2008). Along this line, O'Loughlin et al. (2004) also proposed three levels of customer experience: brand experience, transactional experience and relational experience. Meanwhile, Jain et al. (2017) distinguished three value creation stages in regard to customer experience: value in pre-use, value in use and value in post-use.

Ramaseshan and Stein (2014) also specify that a consumer's experience with a brand is influenced by several brand clues, such as product design, identity, packaging, distribution, locations and marketing communications. This approach is built on the foundation that consumers "consume" and continually experience a series of multisensory interactions between them and firms at every touchpoint from pre-purchase through to post-purchase stages. Studies have also stated that from the consumer's perspective, Consumer-Brand Experience forms the basis for a holistic evaluation of the brand (Khan \& Rahman, 2015; Nysveen et al., 2013). Thus, the behavioral intentions are influenced by emotions during the pre-, actual and post-consumption stages (Barsky \& Nash, 2002; Cronin et al., 2000; Oliver, 1999; Palmer, 2010).

\subsection{CBEx Is Co-created}

A number of authors have highlighted the importance of developing brands with strong personality that allow consumers to "feel the brand" and to "experience the brand" (Palmer, 2010; Smith \& Wheeler, 2002). In the context of CBEx, experiences are about interactions (contacts) of consumers (human beings) who choose the brands when it matches their needs, values and lifestyle.

CBEx could be viewed from a double point of view. From the firm's perspective, the firm essentially designs, crafts and shapes the experience for the consumer (Berry et al., 2002; Stuart \& Tax, 2004); and from the consumer's perspective (Schmitt, 2011) who shapes and lives the experience on the basis of their being. For this reason, The CBEx is considered a culmination of a customer's interaction (brand relationship) with the brand and also with other actors and factors in a broader environment. Due to the dyadic nature of consumer-brand relationships (Kranzbühler et al., 2018), this experience is co-created by an alignment between the customer's goals and an organization's offering. Thus, brands are no longer under the control of the managers but are progressively created by a continuous set of reciprocal dynamics between firms and consumers as a maker of brand meanings (Andreini et al., 2018; Black \& Veloutsou, 2017; Cova \& Dalli, 2009). In other words, the customer becomes a co-creator and an actor of the entire experience process (Chandler \& Lusch, 2015; De Keyser et al., 2015; Jain et al., 2017; Prahalad \& Ramaswamy, 2004). 


\subsection{CBEx Is Systemic}

CBEx could be approached both as an outcome as well as a process (Jain et al., 2017). There is a great accordance that shows positive CBEx is essential to achieving competitive advantage through customer satisfaction, loyalty and word-of-mouth (Berry et al., 2002; Brakus et al., 2009; Carbone \& Haeckel, 1994; Gentile et al., 2007; Palmer, 2010; Pine \& Gilmore, 1998, 1999; Prahalad \& Ramaswamy, 2004; Rawson et al., 2013; Schmitt, 1999; Shaw \& Ivens, 2002; Verhoef et al., 2009; Vargo \& Lusch, 2004).

The experience system includes sensory perceptions of the brand, brand affect, and the participatory experiences that a consumer may seek with a brand. As research shows, the strength of the brand experience influences consumers' ability to draw inferences about the brand personality that influences brand satisfaction and loyalty (Brakus et al., 2009).

CBEx could be viewed as a consequential process or system shaped by multiple factors (antecedents) and affecting, in turn, the consequences (outcomes). In this regard, the literature is very fragmented and all the antecedents and the consequences that have been studied conceptually or empirically were context specific. From this point of view, it is so necessary for the development of a unified conceptual model with the capacity to mirror this process so it is interpreted as a co-created relationship between consumer and brand.

Actually, CBEx is not just modelled by all those elements set by the firm, instead all these inputs are filtered by environmental characteristics (such as social and economic situations) and by the individual's characteristics (such as prior experiences, mood, feelings, life-style, etc.). Once the CBEx has taken shape, in turn, it causes effects on consumer behavior.

On the basis of the literature, a comprehensive conceptual model can be drawn (Figure 3).

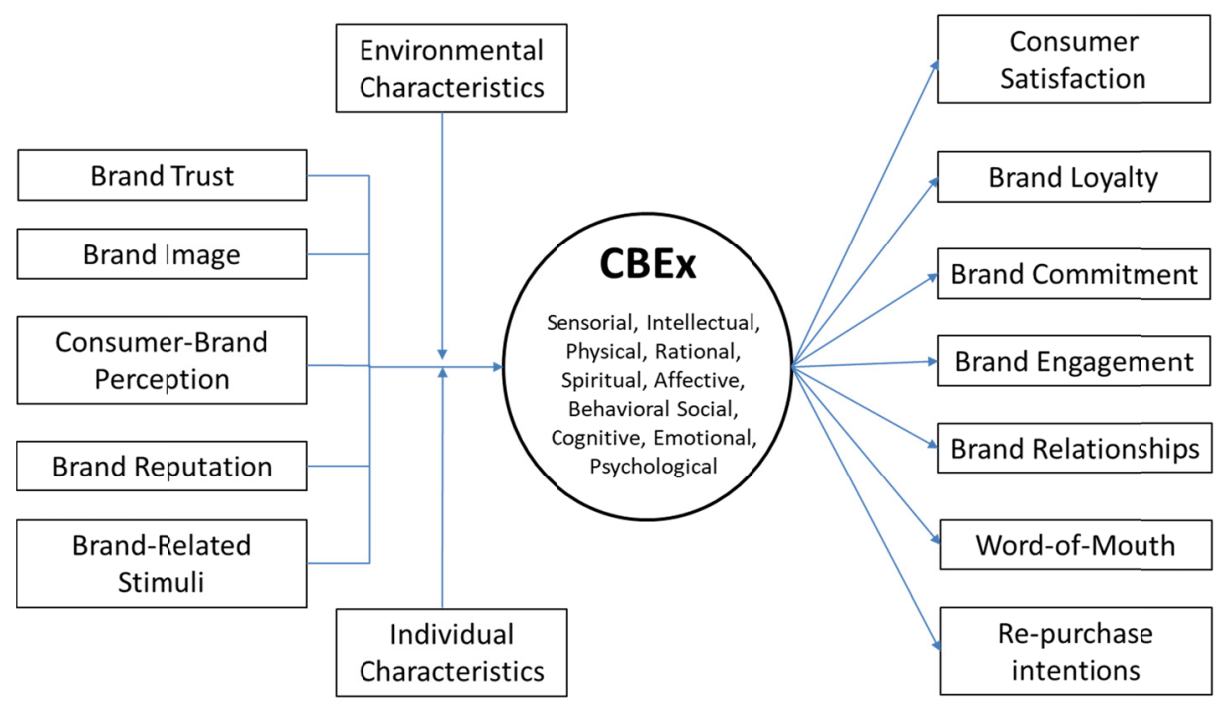

Figure 3. CBEx conceptual model

In conclusion, on the basis of the analysis of the reported studies, Consumer-Brand Experience can be defined as follows:

CBEx is a multi-dimensional and holistic process, characterized by the stratification of all the interactions between the brand and the consumer, which occur in different times and different spaces. It is co-created by both the firm and the consumers and influenced by the environmental and individual characteristics that shape and alter the perception of the experience.

\section{Research Agenda}

This study presents a review of the consumer and brand experience literature, discusses current definitions and understandings of the concept of CBEx and explores the nature and its relation with the consumer behavior. Findings suggest that many significant features of CBEx research have been ignored in prior studies. In this section, the author points out some of the important issues of existing knowledge and provides directions for future 
research. A review of key literature is presented and it gives insight and direction to an understanding of the dimensions of CBEx that help a conceptual framework for future challenges. A number of deductions can be drawn.

The review of the literature shows that even though there is a broad agreement about the importance of Consumer-Brand Experience, there are dissimilar interpretations about its definition, conceptualization, characterization, process and other related concerns. For these reasons, the concept of CBEx calls for more researches in order to establish a shared conceptualization, theoretical background and managerial applications.

This research provides also a comprehensive overview of the Consumer-Brand Experience relationships, antecedents and outcomes and proposes an extension in respect of the previous models. The findings reveal new generalizations about the relationship between CBEx and the other relevant constructs. Specifically, the findings demonstrate that the stronger the consumer experience is with a brand, the stronger the consumer tends to commit to this brand and it is more probable he or she becomes attached to it.

Considering the subjective dimension of the CBEx, the next stage of research is to move beyond the focus of a limited set of elements under the control of the firm to a broader understanding of the multiple factors both within and outside the firm's control that impact on the consumer's experience. Additionally, the next stage of research should focus on a richer conceptualization of the CBEx that not only catches cognitive and affective evaluations but also includes intellectual, psychological and behavioral components. In fact, although a solid background exists, there is a need for additional research to understand how social environment and subjective dimensions impact on CBEx. The study highlights the importance of CBEx as a basic psychological process that enables formation of committed and meaningful relations between brands and consumers. Even though the literature provides a strong theoretical foundation for understanding the related key concepts to CBEx, the next step of the development of the literature should move towards a deeper comprehension of the components of the CBEx. There is a need for the exploration of these components that shape $\mathrm{CBEx}$, in fact, in addition to the affective and cognitive state, CBEx seems to incorporate other states including sensorial, relational and psychological aspects of the consumer.

Regarding the holistic dimension, another important issue is that CBEx is not just limited to the customer's interaction with a brand at the moment of the purchase. Instead, it is impacted by a combination of experiences that evolves over time and space, including search, advertising and other brand stimuli purchases, consumption and after sales phases of the experience (Neslin et al., 2006; Verhoef et al., 2009). This concept calls for a more deep exploration of the construct and the development of measurement scales, which endow the component states to be verified and measured. Future studies should use more interpretive perspectives in order to obtain deeper insight into consumer experience with brands.

Moreover, from an academic point of view, this study contributes to growing research on CBEx by conceptually addressing the relationships across experiences and its antecedents and outcomes. On the basis of the elements identified in consumer and brand experience literature, a conceptual framework has been provided to carry forward CBEx antecedents and consequences together. Future researches need to examine the antecedents of CBEx in different contexts and evaluate their possible outcomes in order to generalize the conceptual model. There is support to suggest that there is a strong relationship between the Consumer-Brand Experience and its antecedents and effects. Researchers should not only determine the validity of this framework in different product or service categories but also empirically highlight the importance of each antecedent in the formation, development and shaping of the CBEx. Consistent with what has already been said, it is, in addition, necessary determine the controllability of the antecedents, in other words, understand which variables are under the firm's control, which are partially controllable, and which variables escape from the firm's control.

Brand loyalty and customer satisfaction are highly discussed and empirically tested as outcomes but only a few studies have focused on other important outcomes, like brand commitment, brand engagement and re-purchase intention. There is a need to examine these brand and consumer behavior-related outcomes, and also in different contexts. Additionally, further development should establish if constructs, such as brand trust or brand engagement, affecting CBEx are affected by them or are parts of the overall process.

Such study could also empirically test these important antecedents and consequences of consumers' experience with a brand and check whether some differences in the degree of consumers' experiences and commitment do appear. In addition, an interesting future research would be to test how CBEx influences re-purchase behavior. Researches should also replicate these findings in the context of different types of brands, such as product, service, and retail brands. 
The presented framework in only conceptual and calls for further development and empirical investigations in order to build academic understanding of this topic and to identify the relationships between these outcome variables. Thus, the conceptual model presented should be developed into a research model that must be empirically tested by the support of SEM technique. Moreover, there is a need for a more specific measure of CBEx and its link to firm performance.

Another issue is the identification of an optimal level of experience (Palmer, 2010). Future advancements should also develop a robust measurement of CBEx in order to measure the relationship between CBEx and its antecedents and consequences and in order to predict consumer behavior. A number of challenges call scholars in the development of a measurement scale for CBEx. Probably the main problem in developing a unified measurement scale is the complexity of the environment, the innumerable factors to take into consideration and the fact that CBEx is context specific.

\section{Managerial Implications}

The increasing importance and the development of consumer and brand experience in the last 35 years has delivered practical insights about shaping, evolving and providing unique and memorable experiences during the overall relationship between consumers and brands to enhance customer satisfaction as an important managerial driver for firms. Creating a strong customer experience is now a leading management objective and marketers now, more than in the past, have the ability to customize experiences. Firms must not only acknowledge the factors that contribute to the CBEx but they should also manage these factors. In short, CBEx requires more attention due to its practical relevance and managerial implications can be drawn from this literature review.

The proposed framework suggests that marketers need to be aware that functional benefits are important but it is also important to recognize the experiential state of the consumer as one of the key drivers in developing marketing strategies. Managers need to focus on consumers' expectations and clearly define the role of consumer as a co-creator of experiences. Therefore, managers should incorporate a bilateral view and identify what constitutes the experience for their customers. Moreover, an understanding of experience factors, elements, and the related responses from consumers can enhance firms in the management of experiences. The findings of the study indicate that brands play an important role in the lives of individuals and can even influence the construction of a person's identity. Specifically, the results suggest that by focusing on factors that influence Consumer-Brand Experience, brand managers could achieve some important and desired consequences, most notably consumers' commitment and their willingness to generate positive WOM.

Firms have to realize the importance of CBEx as an instrument for achieving competitive advantage. Experience is a transitory phenomenon, so a specific experience is incapable of giving a competitive advantage for a firm. Instead, it is more appropriate for managers to think about how a set of experiences will develop over time in order to achieve a sustainable competitive advantage. Nowadays, firms must implement apposite measurements, metrics and techniques in order to map the experiential process and its outcomes. It can help the management to design strategies aimed to shape and affect consumers' perceptions about experiences.

To conclude, managers should focus on consumers' behavior processes. The existence of the emotional aspects and the fact that consumers are not perfectly rational can modify the way that brand stimuli are perceived. Through focusing on what constitutes the CBEx and how it is perceived by consumers, firms can try to manage the design and the shape of the experience that they want to create. Focusing on brand strategies around the experience concept will help marketers craft better and effective marketing strategies to enhance Consumer-Brand Experience and, consequently, build more memorable and powerful brands. Furthermore, with appropriate tools, systematically measuring the process of experience and developing marketing strategies to manage this field, firms may be able to enhance the wellness of consumers, the firm itself and, as a last resort, society.

\section{Limitations of the Study}

Although this study has considered every possible article related to consumer and brand experience, it has some limitations: First, the decision to focus only on the articles published in journals could have some restrictions; in fact, it may exclude some researches, books, thesis dissertations that cover this CBEx topic. Second, this paper explores articles for analysis by searching for the term "brand" or "consumer experience" and related keywords and selects only those papers that appeared in response to the searched terms. This could conduce to the automatic exclusion of papers that might have addressed similar topics. Third, this work takes into account all the papers published in marketing and consumer behavior journals but omits journals concerning philosophy and pure psychological topics. 


\section{References}

Aaker, J., Fournier, S., \& Brasel, S. A. (2004). When good brands do bad. Journal of Consumer Research, 31(1), 1-16. https://doi.org/10.1086/383419

Addis, M., \& Holbrook, M. B. (2001). On the conceptual link between mass customisation and experiential consumption: an explosion of subjectivity. Journal of Consumer Behaviour: An International Research Review, 1(1), 50-66. https://doi.org/10.1002/cb.53

Alloza, A. (2008). Brand engagement and brand experience at BBVA, the transformation of a 150 years old company. Corporate Reputation Review, 11(4), 371-379. https://doi.org/10.1057/crr.2008.31

Andreini, D., Pedeliento, G., Zarantonello, L., \& Solerio, C. (2018). A renaissance of brand experience: Advancing the concept through a multi-perspective analysis. Journal of Business Research, 91, 123-133. https://doi.org/10.1016/j.jbusres.2018.05.046

Andrew, G. (2003). Brands that get noticed. Marketing Research, 29-31.

Arnould, E. J., Price, L., \& Zinkhan, G. M. (2002). Consumers. McGraw-Hill/Irwin.

Atwal, G., \& Williams, A. (2009). Luxury brand marketing-the experience is everything!. Journal of Brand Management, 16(5-6), 338-346. https://doi.org/10.1057/bm.2008.48

Babin, B. J., Darden, W. R., \& Griffin, M. (1994). Work and/or fun: measuring hedonic and utilitarian shopping value. Journal of Consumer Research, 20(4), 644-656. https://doi.org/10.1086/209376

Bagdare, S. (2013). Antecedents of Retail Customer Experience. Journal of Marketing \& Communication, 8(3), $45-51$.

Bagdare, S. (2016). Retail customer experience: a research agenda. CLEAR International Journal of Research in Commerce \& Management, 7(4), 55-58.

Bagozzi, R. P., Gopinath, M., \& Nyer, P. U. (1999). The role of emotions in marketing. Journal of the Academy of Marketing Science, 27(2), 184-206. https://doi.org/10.1177/0092070399272005

Barclay, S., Momen, N., Case-Upton, S., Kuhn, I., \& Smith, E. (2011). End-of-life care conversations with heart failure patients: a systematic literature review and narrative synthesis. British Journal of General Practice, 61(582), e49-e62. https://doi.org/10.3399/bjgp11X549018

Barnham, C. (2008). Instantiation: reframing brand communication. International Journal of Market Research, 50(2), 203-215. https://doi.org/10.1177/147078530805000205

Barsky, J., \& Nash, L. (2002). Evoking emotion: affective keys to hotel loyalty. Cornell Hotel and Restaurant Administration Quarterly, 43(1), 39-46. https://doi.org/10.1016/S0010-8804(02)80007-6

Başer, İ. U., Cintamür, İ. G., \& Arslan, F. M. (2015). Examining the effect of brand experience on consumer satisfaction, brand trust and brand loyalty. Marmara University Journal of Economic \& Administrative Sciences, 37(2).

Beltagui, A., Candi, M., \& Riedel, J. C. (2016). Setting the stage for service experience: design strategies for functional services. Journal of Service Management, 27(5), 751-772. https://doi.org/10.1108/JOSM-08-2015-0234

Beltagui, A., Darler, W., \& Candi, M. (2015). Measuring the deliverable and impressible dimensions of service experience. Creativity and Innovation Management, 24(3), 478-492. https://doi.org/10.1111/caim.12130

Berry, L. L., Carbone, L. P., \& Haeckel, S. H. (2002). Managing the total customer experience. MIT Sloan Management Review, 43(3), 85-89.

Bettingen, J. F., \& Luedicke, M. K. (2009). Can brands make us happy? A research framework for the study of brands and their effects on happiness. ACR North American.

Bhandari, s. (2016). Understanding the models of customer experience. CLEAR International Journal of Research in Commerce \& Management, 7(8).

Black, I., \& Veloutsou, C. (2017). Working consumers: Co-creation of brand identity, consumer identity and brand community identity. Journal of Business Research, 70, 416-429. https://doi.org/10.1016/j.jbusres.2016.07.012 
Bolton, N. R., Gustafsson, A., McColl-Kennedy, J., Sirianni, N. J., \& Tse, D. K. (2014). Small details that make big differences: a radical approach to consumption experience as a firm's differentiating strategy. Journal of Service Management, 25(2), 253-274. https://doi.org/10.1108/JOSM-01-2014-0034

Bonnin, G. (2006). Physical environment and service experience: an appropriation-based model. Journal of Services Research, 6, 45.

Brakus, J. J., Schmitt, B. H., \& Zarantonello, L. (2009). Brand Experience: What Is It? How Is It Measured? Does It Affect Loyalty?. Journal of Marketing, 73(3), 52-68. https://doi.org/10.1509/jmkg.73.3.052

Briner, R. B., Denyer, D., \& Rousseau, D. M. (2009). Evidence-based management: concept cleanup time?. Academy of Management Perspectives, 23(4), 19-32. https://doi.org/10.5465/amp.23.4.19

Brun, I., Rajaobelina, L., Ricard, L., \& Berthiaume, B. (2017). Impact of customer experience on loyalty: a multichannel examination. The Service Industries Journal, 37(5-6), 317-340. https://doi.org/10.1080/02642069.2017.1322959

Callahan, J. L. (2014). Writing literature reviews a reprise and update. Human Resource Development Review, 13(3), 271-275. https://doi.org/10.1177/1534484314536705

Carbone, L. P. (1998). Total customer experience drives value. Management review, 87(7), 62.

Carbone, L. P., \& Haeckel, S. H. (1994). Engineering customer experiences. Marketing Management, 3(3), 819.

Carpenter, J. M., \& Moore, M. (2009). Utilitarian and hedonic shopping value in the US discount sector. Journal of Retailing and Consumer Services, 16(1), 68-74. https://doi.org/10.1016/j.jretconser.2008.10.002

Carù, A., \& Cova, B. (2003). Revisiting consumption experience: A more humble but complete view of the concept. Marketing theory, 3(2), 267-286. https://doi.org/10.1177/14705931030032004

Chahal, H., Kaur, G., \& Rani, A. (2015). Exploring the dimensions of customer experience and its impact on word-of-mouth: a study of credit cards. Journal of Services Research, 15(2), 7.

Chakravorti, S. (2011). Managing organizational culture change and knowledge to enhance customer experiences: analysis and framework. Journal of Strategic Marketing, 19(02), 123-151. https://doi.org/10.1080/0965254X.2010.529160

Chandler, J. D., \& Lusch, R. F. (2015). Service systems: a broadened framework and research agenda on value propositions, engagement, and service experience. Journal of Service Research, 18(1), 6-22. https://doi.org/10.1177/1094670514537709

Chang, P. L., \& Chieng, M. H. (2006). Building consumer-brand relationship: A cross-cultural experiential view. Psychology \& Marketing, 23(11), 927-959. https://doi.org/10.1002/mar.20140

Chang, T. Y., \& Horng, S. C. (2010). Conceptualizing and measuring experience quality: the customer's perspective. The Service Industries Journal, 30(14), 2401-2419. https://doi.org/10.1080/02642060802629919

Chattopadhyay, A., \& Laborie, J. L. (2005). Managing brand experience: The market contact audit ${ }^{\mathrm{TM}}$. Journal of Advertising Research, 45(1), 9-16. https://doi.org/10.1017/S0021849905050129

Chen, L. S. L. (2012). What drives cyber shop brand equity? An empirical evaluation of online shopping system benefit with brand experience. International Journal of Business and Information, 7(1).

Chun, H. H., Diehl, K., \& MacInnis, D. J. (2017). Savoring an Upcoming Experience Affects Ongoing and Remembered Consumption Enjoyment. Journal of Marketing, 81(3), 96-110. https://doi.org/10.1509/jm.15.0267

Cleff, T., Lin, I. C., \& Walter, N. (2014). Can You Feel It? The Effect of Brand Experience on Brand Equity. IUP Journal of Brand Management, 11(2), 7-27.

Cleff, T., Walter, N., \& Xie, J. (2018). The Effect of Online Brand Experience on Brand Loyalty: A Web of Emotions. IUP Journal of Brand Management, 15(1).

Cole-Colander, C. (2003). Designing the customer experience. Building Research \& Information, 31(5), 357366. https://doi.org/10.1080/0961321032000088025 
Cook, D. J., Mulrow, C. D., \& Haynes, R. B. (1997). Systematic reviews: synthesis of best evidence for clinical decisions. Annals of Internal Medicine, 126(5), 376-380. https://doi.org/10.7326/0003-4819-126-5-199703010-00006

Cova, B., \& Dalli, D. (2009). Working consumers: the next step in marketing theory?. Marketing Theory, 9(3), 315-339. https://doi.org/10.1177/1470593109338144

Cronin Jr, J. J., Brady, M. K., \& Hult, G. T. M. (2000). Assessing the effects of quality, value, and customer satisfaction on consumer behavioral intentions in service environments. Journal of Retailing, 76(2), 193218. https://doi.org/10.1016/S0022-4359(00)00028-2

Daugherty, T., Li, H., \& Biocca, F. (2008). Consumer learning and the effects of virtual experience relative to indirect and direct product experience. Psychology \& Marketing, 25(7), 568-586. https://doi.org/10.1002/mar.20225

De Keyser, A., Schepers, J., \& Konuş, U. (2015). Multichannel customer segmentation: Does the after-sales channel matter? A replication and extension. International Journal of Research in Marketing, 32(4), 453456. https://doi.org/10.1016/j.ijresmar.2015.09.005

de Oliveira Santini, F., Ladeira, W. J., Sampaio, C. H., \& Pinto, D. C. (2018). The brand experience extended model: a meta-analysis. Journal of Brand Management, 1-17. https://doi.org/10.1057/s41262-018-0104-6

Denyer, D., \& Tranfield, D. (2009). Producing a systematic review. In D. Buchanan (Ed.), The Sage Handbook of Organizational Research Methods (pp. 671-689). London: Sage.

Dumitrescu, L., Stanciu, O., Țichindelean, M., \& Vinerean, S. (2012). The Importance of Establishing Customer Experiences. Studies in Business and Economics, 7(1), 56-61.

Escalas, J. E., \& Bettman, J. R. (2005). Self-construal, reference groups, and brand meaning. Journal of Consumer Research, 32(3), 378-389. https://doi.org/10.1086/497549

Fournier, S. (1998). Consumers and their brands: Developing relationship theory in consumer research. Journal of Consumer Research, 24(4), 343-373. https://doi.org/10.1086/209515

Frow, P., \& Payne, A. (2007). Towards the 'perfect'customer experience. Journal of Brand Management, 15(2), 89-101. https://doi.org/10.1057/palgrave.bm.2550120

Gentile, C., Spiller, N., \& Noci, G. (2007). How to Sustain the Customer Experience: An Overview of Experience Components That Co-Create Value with the Customer. European Management Journal, 25(5), 395-410. https://doi.org/10.1016/j.emj.2007.08.005

Grace, D., \& O'Cass, A. (2004). Examining service experiences and post-consumption evaluations. Journal of Services Marketing, 18(6), 450-461. https://doi.org/10.1108/08876040410557230

Grégoire, Y., Tripp, T. M., \& Legoux, R. (2009). When customer love turns into lasting hate: The effects of relationship strength and time on customer revenge and avoidance. Journal of Marketing, 73(6), 18-32. https://doi.org/10.1509/jmkg.73.6.18

Grönroos, C. (2006). On defining marketing: finding a new roadmap for marketing. Marketing Theory, 6(4), 395-417. https://doi.org/10.1177/1470593106069930

Ha, H.-Y., \& Perks, H. (2005). Effects of Consumer Perceptions of Brand Experience on the Web: Brand Familiarity, Satisfaction and Brand Trust. Journal of Consumer Behaviour, 4(6), 438-52. https://doi.org/10.1002/cb.29

Haeckel, S. H., Carbone, L. P., \& Berry, L. L. (2003). How to lead the customer experience. Marketing Management, 12(1), 18-18.

Harris, K., Baron, S., \& Parker, C. (2000). Understanding the consumer experience: It's' good to talk'. Journal of Marketing Management, 16(1-3), 111-127. https://doi.org/10.1362/026725700785100505

Havlena, W. J., \& Holbrook, M. B. (1986). The varieties of consumption experience: comparing two typologies of emotion in consumer behavior. Journal of consumer research, 13(3), 394-404. https://doi.org/10.1086/209078

Helkkula, A., \& Kelleher, C. (2010). Circularity of customer service experience and customer perceived value. Journal of Customer Behaviour, 9(1), 37-53. https://doi.org/10.1362/147539210X497611 
Hepola, J., Karjaluoto, H., \& Hintikka, A. (2017). The effect of sensory brand experience and involvement on brand equity directly and indirectly through consumer brand engagement. Journal of Product \& Brand Management, 26(3), 282-293. https://doi.org/10.1108/JPBM-10-2016-1348

Hoch, S. J. (2002). Product experience is seductive. Journal of Consumer Research, 29(3), 448-454. https://doi.org/10.1086/344422

Holbrook, M. B. (2006). Consumption experience, customer value, and subjective personal introspection: An illustrative photographic essay. Journal of business research, 59(6), 714-725. https://doi.org/10.1016/j.jbusres.2006.01.008

Holbrook, M. B., \& Hirschman, E. C. (1982). The experiential aspects of consumption: Consumer fantasies, feelings, and fun. Journal of Consumer Research, 9(2), 132-140. https://doi.org/10.1086/208906

Homburg, C., Jozić, D., \& Kuehnl, C. (2017). Customer experience management: toward implementing an evolving marketing concept. Journal of the Academy of Marketing Science, 45(3), 377-401. https://doi.org/10.1007/s11747-015-0460-7

Huang, C. C. (2017). The impacts of brand experiences on brand loyalty: mediators of brand love and trust. Management Decision, 55(5), 915-934. https://doi.org/10.1108/MD-10-2015-0465

Hultén, B. (2011). Sensory marketing: the multi-sensory brand-experience concept. European Business Review, 23(3), 256-273. https://doi.org/10.1108/09555341111130245

Hwang, J., \& Seo, S. (2016). A critical review of research on customer experience management: Theoretical, methodological and cultural perspectives. International Journal of Contemporary Hospitality Management, 28(10), 2218-2246. https://doi.org/10.1108/IJCHM-04-2015-0192

Iglesias, O., Singh, J. J., \& Batista-Foguet, J. M. (2011). The role of brand experience and affective commitment in determining brand loyalty. Journal of Brand Management, 18(8), 570-582. https://doi.org/10.1057/bm.2010.58

Ishida, C., \& Taylor, S. A. (2012). Retailer brand experience, brand experience congruence, and consumer satisfaction. Journal of Consumer Satisfaction, Dissatisfaction and Complaining Behavior, 25, 63.

Islam, J. U., \& Rahman, Z. (2016). The transpiring journey of customer engagement research in marketing: A systematic review of the past decade. Management Decision, 54(8), 2008-2034. https://doi.org/10.1108/MD-01-2016-0028

Ismail, A. R. (2011). Experience marketing: An empirical investigation. Journal of Relationship Marketing, 10(3), 167-201. https://doi.org/10.1080/15332667.2011.599703

Jafari, S. M., Forouzandeh, M., Ghazvini, S. A., Safahani, N., \& Moslehi, M. (2016). The impact of online brand experience on customer's satisfaction and loyalty. International Business Management, 10(5), 599-603.

Jain, R., \& Bagdare, S. (2009). Determinants of Customer Experience in New Format Retail Stores. Journal of Marketing \& Communication, 5(2).

Jain, R., Aagja, J., \& Bagdare, S. (2017). Customer experience-a review and research agenda. Journal of Service Theory and Practice, 27(3), 642-662. https://doi.org/10.1108/JSTP-03-2015-0064

Janiszewski, C. (2010). The Consumer Experience. Advances in Consumer Research, 37, 1-6.

Johnson, A. R., Matear, M., \& Thomson, M. (2010). A coal in the heart: Self-relevance as a post-exit predictor of consumer anti-brand actions. Journal of Consumer Research, 38(1), 108-125. https://doi.org/10.1086/657924

Jones, M. A., Reynolds, K. E., \& Arnold, M. J. (2006). Hedonic and utilitarian shopping value: Investigating differential effects on retail outcomes. Journal of Business Research, 59(9), 974-981. https://doi.org/10.1016/j.jbusres.2006.03.006

Jung, L. H., \& Soo, K. M. (2012). The effect of brand experience on brand relationship quality. Academy of Marketing Studies Journal, 16(1), 87-98.

Keller, K. L., \& Lehmann, D. R. (2006). Brands and branding: Research findings and future priorities. Marketing Science, 25(6), 740-759. https://doi.org/10.1287/mksc.1050.0153

Keränen, J., Piirainen, K. A., \& Salminen, R. T. (2012). Systematic review on B2B branding: research issues and avenues for future research. Journal of Product \& Brand Management, 21(6), 404-417. https://doi.org/10.1108/10610421211264892 
Khan, I., \& Fatma, M. (2017). Antecedents and outcomes of brand experience: an empirical study. Journal of Brand Management, 24(5), 439-452. https://doi.org/10.1057/s41262-017-0040-x

Khan, I., \& Rahman, Z. (2015). Brand experience anatomy in retailing: An interpretive structural modeling approach. Journal of Retailing and Consumer Services, 24, 60-69. https://doi.org/10.1016/j.jretconser.2015.02.003

Kim, S., Cha, J., Knutson, B. J., \& Beck, J. A. (2011). Development and testing of the Consumer Experience Index (CEI). Managing Service Quality: An International Journal, 21(2), 112-132. https://doi.org/10.1108/09604521111113429

Klaus, P. P., \& Maklan, S. (2013). Towards a better measure of customer experience. International Journal of Market Research, 55(2), 227-246. https://doi.org/10.2501/IJMR-2013-021

Klaus, P., \& Nguyen, B. (2013). Exploring the role of the online customer experience in firms' multi-channel strategy: An empirical analysis of the retail banking services sector. Journal of Strategic Marketing, 21(5), 429-442. https://doi.org/10.1080/0965254X.2013.801610

Kranzbühler, A. M., Kleijnen, M. H., Morgan, R. E., \& Teerling, M. (2018). The multilevel nature of customer experience research: an integrative review and research agenda. International Journal of Management Reviews, 20(2), 433-456. https://doi.org/10.1111/ijmr.12140

Lanier Jr, C. D., \& Rader, C. S. (2015). Consumption experience: An expanded view. Marketing Theory, 15(4), 487-508. https://doi.org/10.1177/1470593115581721

Lemke, F., Clark, M., \& Wilson, H. (2011). Customer experience quality: an exploration in business and consumer contexts using repertory grid technique. Journal of the Academy of Marketing Science, 39(6), 846-869. https://doi.org/10.1007/s11747-010-0219-0

Lemon, K. N., \& Verhoef, P. C. (2016). Understanding customer experience throughout the customer journey. Journal of Marketing, 80(6), 69-96. https://doi.org/10.1509/jm.15.0420

Long-Tolbert, S., Till, B. D., \& Swaminathan, S. (2006). Product Attribute Evaluations: Role of Consumer Experience and Halo Effects. Advances in Consumer Research, 33, 678.

Lundqvist, A., Liljander, V., Gummerus, J., \& Van Riel, A. (2013). The impact of storytelling on the consumer brand experience: The case of a firm-originated story. Journal of Brand Management, 20(4), 283-297. https://doi.org/10.1057/bm.2012.15

Maklan, S., \& Klaus, P. (2011). Customer experience: are we measuring the right things?. International Journal of Market Research, 53(6), 771-792. https://doi.org/10.2501/IJMR-53-6-771-792

Maklan, S., Antonetti, P., \& Whitty, S. (2017). A Better Way to Manage Customer Experience: Lessons from the Royal Bank of Scotland. California Management Review, 59(2), 92-115. https://doi.org/10.1177/0008125617695285

Manhas, D., \& Chauhan, V. (2017). Dimensional Analysis of Customer Experience in the Civil Aviation Sector. In Hospitality Marketing and Consumer Behavior (pp. 75-101). Apple Academic Press.

Mascarenhas, O. A., Kesavan, R., \& Bernacchi, M. (2006). Lasting customer loyalty: a total customer experience approach. Journal of Consumer Marketing, 23(7), 397-405. https://doi.org/10.1108/07363760610712939

McAlexander, J. H., Schouten, J. W., \& Koenig, H. F. (2002). Building brand community. Journal of Marketing, 66(1), 38-54. https://doi.org/10.1509/jmkg.66.1.38.18451

Minkiewicz, J., Evans, J., \& Bridson, K. (2014). How do consumers co-create their experiences? An exploration in the heritage sector. Journal of Marketing Management, 30(1-2), 30-59. https://doi.org/10.1080/0267257X.2013.800899

Morgan-Thomas, A., \& Veloutsou, C. (2013). Beyond technology acceptance: Brand relationships and online brand experience. Journal of Business Research, 66(1), 21-27. https://doi.org/10.1016/j.jbusres.2011.07.019

Morrison, S., \& Crane, F. G. (2007). Building the Service Brand by Creating and Managing an Emotional Brand Experience. Journal of Brand Management, 14(5), 410-21. https://doi.org/10.1057/palgrave.bm.2550080

MSI. (2018). MSI Research Initiative on Customer Experience. Retrieved June, 15, 2018, from http://www.msi.org/research/research-competitions-and-calls-for-papers/research-competition/msi-research -initiative-on-customer-experience/ 
Nambisan, P., \& Watt, J. H. (2011). Managing customer experiences in online product communities. Journal of Business Research, 64(8), 889-895. https://doi.org/10.1016/j.jbusres.2010.09.006

Nejad, F. M., Samadi, S., Ashraf, Y. A. P., \& Tolabi, Z. (2015). Affecting Factors of Consumers' Intent to Buy in the Food Industry by Emphasizing Brand Experience (Case Study: Mashhad TABAROK Company). Iranian Journal of Management Studies, 8(2), 243.

Neslin, S. A., Grewal, D., Leghorn, R., Shankar, V., Teerling, M. L., Thomas, J. S., \& Verhoef, P. C. (2006). Challenges and opportunities in multichannel customer management. Journal of Service Research, 9(2), 95-112. https://doi.org/10.1177/1094670506293559

Newbert, S. L. (2007). Empirical research on the resource-based view of the firm: an assessment and suggestions for future research. Strategic Management Journal, 28(2), 121-146. https://doi.org/10.1002/smj.573

Novak, T. P., Hoffman, D. L., \& Duhachek, A. (2003). The influence of goal-directed and experiential activities on online flow experiences. Journal of consumer psychology, 13(1-2), 3-16. https://doi.org/10.1207/153276603768344744

Novak, T. P., Hoffman, D. L., \& Yung, Y. F. (2000). Measuring the customer experience in online environments: A structural modeling approach. Marketing science, 19(1), 22-42. https://doi.org/10.1287/mksc.19.1.22.15184

Nysveen, H., \& Pedersen, P. E. (2014). Influences of cocreation on brand experience. International Journal of Market Research, 56(6), 807-832. https://doi.org/10.2501/IJMR-2014-016

Nysveen, H., Pedersen, P. E., \& Skard, S. (2013). Brand experiences in service organizations: Exploring the individual effects of brand experience dimensions. Journal of Brand Management, 20(5), 404-423. https://doi.org/10.1057/bm.2012.31

Oliver, R. L. (1999). Whence consumer loyalty?. The Journal of Marketing, 63, 33-44. https://doi.org/10.2307/1252099

O'Loughlin, D., Szmigin, I., \& Turnbull, P. (2004). From relationships to experiences in retail financial services. International Journal of Bank Marketing, 22(7), 522-539. https://doi.org/10.1108/02652320410567935

Ong, C. H., Lee, H. W., \& Ramayah, T. (2018). Impact of brand experience on loyalty. Journal of Hospitality Marketing \& Management, 1-20. https://doi.org/10.1080/19368623.2018.1445055

Ortmeyer, G., \& Huber, J. (1991). Brand experience as a moderator of the negative impact of promotions. Marketing Letters, 2(1), 35-45. https://doi.org/10.1007/BF00435194

Palmer, A. (2010). Customer experience management: a critical review of an emerging idea. Journal of Services Marketing, 24(3), 196-208. https://doi.org/10.1108/08876041011040604

Patterson, A., Hodgson, J., \& Shi, J. (2008). Chronicles of'customer experience': the downfall of Lewis's foretold. Journal of Marketing Management, 24(1-2), 29-45. https://doi.org/10.1362/026725708X273902

Pettit, R. (2005). A critical review of "Managing brand experience: the market contact audit"M". Journal of Advertising Research, 45(1), 17-18. https://doi.org/10.1017/S0021849905050130

Pine, B. J., \& Gilmore, J. H. (1998). Welcome to the experience economy. Harvard Business Review, 76, 97105.

Pittaway, L., \& Cope, J. (2007). Entrepreneurship education: a systematic review of the evidence. International Small Business Journal, 25(5), 479-510. https://doi.org/10.1177/0266242607080656

Pittaway, L., Robertson, M., Munir, K., Denyer, D., \& Neely, A. (2004). Networking and innovation: a systematic review of the evidence. International Journal of Management Reviews, 5(3-4), 137-168. https://doi.org/10.1111/j.1460-8545.2004.00101.x

Popa, V., \& Barna, M. (2013). Customer and shopper experience management. Valahian Journal of Economic Studies, 4(2), 81-88.

Popay, J., Roberts, H., Sowden, A., Petticrew, M., Arai, L., Rodgers, M., \& Duffy, S. (2006). Guidance on the conduct of narrative synthesis in systematic reviews. A product from the ESRC methods programme, Version 1, b92.

Prahalad, C. K., \& Ramaswamy, V. (2004). Co-creation experiences: The next practice in value creation. Journal of Interactive Marketing, 18(3), 5-14. https://doi.org/10.1002/dir.20015 
Ramaseshan, B., \& Stein, A. (2014). Connecting the dots between brand experience and brand loyalty: The mediating role of brand personality and brand relationships. Journal of Brand Management, 21(7-8), 664 683. https://doi.org/10.1057/bm.2014.23

Rawson, A., Duncan, E., \& Jones, C. (2013). The truth about customer experience. Harvard Business Review, 91(9), 90-98.

Riivits-Arkonsuo, I., \& Leppiman, A. (2014). Online Word-of-Mouth on Brands and Experience Marketing. Journal of Management \& Change.

Roederer, C. (2012). A contribution to conceptualizing the consumption experience: Emergence of the dimensions of an experience through life narratives. Recherche et Applications en Marketing (English Edition), 27(3), 81-95. https://doi.org/10.1177/205157071202700304

Rose, S., Clark, M., Samouel, P., \& Hair, N. (2012). Online customer experience in e-retailing: an empirical model of antecedents and outcomes. Journal of Retailing, 88(2), 308-322. https://doi.org/10.1016/j.jretai.2012.03.001

Rose, S., Hair, N., \& Clark, M. (2010). Online customer experience: A review of the business-to-consumer online purchase context. International Journal of Management Reviews, 13(1), 24-39. https://doi.org/10.1111/j.1468-2370.2010.00280.x

Ryder, I. (2007). Customer experience. Journal of Brand Management, 15(2), 85-88. https://doi.org/10.1057/palgrave.bm.2550127

Saari, U. A., \& Mäkinen, S. J. (2017). Measuring brand experiences cross-nationally. Journal of Brand Management, 24(1), 86-104. https://doi.org/10.1057/s41262-016-0022-4

Schmitt, B. (1999). Experiential marketing. Journal of Marketing Management, 15(1-3), 53-67. https://doi.org/10.1362/026725799784870496

Schmitt, B. (2009). The concept of brand experience. Journal of Brand Management, 16(7), 417. https://doi.org/10.1057/bm.2009.5

Schmitt, B. (2011). Experience marketing: concepts, frameworks and consumer insights. Foundations and Trends ${ }^{\circledR}$ in Marketing, 5(2), 55-112. https://doi.org/10.1561/1700000027

Schmitt, B. H., \& Rogers, D. L. (2008). Handbook on Brand and Experience Management. Edward Elgar. https://doi.org/10.4337/9781848446151

Schmitt, B. H., \& Zarantonello, L. (2013). Consumer experience and experiential marketing: a critical review. Review of Marketing Research, 10, 25-61. https://doi.org/10.1108/S1548-6435(2013)0000010006

Schmitt, B., Brakus, J. J., \& Zarantonello, L. (2015). From experiential psychology to consumer experience. Journal of Consumer Psychology, 25(1), 166-171. https://doi.org/10.1016/j.jcps.2014.09.001

Sharma, M., \& Chaubey, D. S. (2014). An Empirical Study of Customer Experience and its Relationship with Customer Satisfaction towards the Services of Banking Sector. Journal of Marketing \& Communication, 9(3).

Sharma, M., Tiwari, P., \& Chaubey, D. S. (2016). Summarizing factors of customer experience and building a structural model using total interpretive structural modelling technology. Global Business Review, 17(3), 730-741. https://doi.org/10.1177/0972150916630825

Shaw, C., \& Ivens, J. (2002). Building great customer experiences (Vol. 241). London: Palgrave. https://doi.org/10.1057/9780230554719

Sheth, J. N., Mittal, B., \& Newman, B. I. (1999). Consumer behavior and beyond. NY: Harcourt Brace.

Shobeiri, S., Mazaheri, E., \& Laroche, M. (2018). Creating the right customer experience online: The influence of culture. Journal of Marketing Communications, 24(3), 270-290. https://doi.org/10.1080/13527266.2015.1054859

Smith, S., \& Wheeler, J. (2002). Managing the customer experience: Turning customers into advocates. Pearson Education.

Söderlund, M., \& Sagfossen, S. (2017). The consumer experience: The impact of supplier effort and consumer effort on customer satisfaction. Journal of Retailing and Consumer Services, 39, 219-229. https://doi.org/10.1016/j.jretconser.2017.08.019 
Song, S. (2015). Identifying on-line shopping experiences from the perspective of shopping motives. Academy of Marketing Studies Journal, 19(3), 139.

Stein, A., \& Ramaseshan, B. (2016). Towards the identification of customer experience touch point elements. Journal of Retailing and Consumer Services, 30, 8-19. https://doi.org/10.1016/j.jretconser.2015.12.001

Stuart, F. I., \& Tax, S. (2004). Toward an integrative approach to designing service experiences: lessons learned from the theatre. Journal of Operations Management, 22(6), 609-627. https://doi.org/10.1016/S0272-6963(04)00081-6

Swaminathan, V., Stilley, K., \& Ahluwalia, R. (2009). The role of brand personality and consumer attachment style in strengthening brand relationships. ACR North American Advances.

Thomson, M., MacInnis, D. J., \& Whan Park, C. (2005). The ties that bind: Measuring the strength of consumers' emotional attachments to brands. Journal of Consumer Psychology, 15(1), 77-91. https://doi.org/10.1207/s15327663jcp1501_10

Thorpe, R., Holt, R., Macpherson, A., \& Pittaway, L. (2005). Using knowledge within small and medium-sized firms: A systematic review of the evidence. International Journal of Management Reviews, 7(4), 257-281. https://doi.org/10.1111/j.1468-2370.2005.00116.x

Tranfield, D., Denyer, D., \& Smart, P. (2003). Towards a methodology for developing evidence-informed management knowledge by means of systematic review. British Journal of Management, 14(3), 207-222. https://doi.org/10.1111/1467-8551.00375

Tynan, C., \& McKechnie, S. (2009). Experience marketing: a review and reassessment. Journal of Marketing Management, 25(5-6), 501-517. https://doi.org/10.1362/026725709X461821

van der Westhuizen, L. M. (2018). Brand loyalty: exploring self-brand connection and brand experience. Journal of Product \& Brand Management, 27(2), 172-184. https://doi.org/10.1108/JPBM-07-2016-1281

Vargo, S. L., \& Lusch, R. F. (2004). Evolving to a new dominant logic for marketing. Journal of Marketing, 68(1), 1-17. https://doi.org/10.1108/JPBM-07-2016-1281

Verhoef, P. C., Lemon, K. N., Parasuraman, A., Roggeveen, A., Tsiros, M., \& Schlesinger, L. A. (2009). Customer experience creation: Determinants, dynamics and management strategies. Journal of Retailing, 85(1), 31-41. https://doi.org/10.1016/j.jretai.2008.11.001

Wall-Mullen, E., \& Envick, B. R. (2015). Get a clue: how entrepreneurs can manage the service experience to differentiate themselves \& provide value propositions that maximize customer satisfaction. Entrepreneurial Executive, 20(1), 1-8.

Walls, A. R., Okumus, F., Wang, Y. R., \& Kwun, D. J. W. (2011). An epistemological view of consumer experiences. International Journal of Hospitality Management, 30(1), 10-21. https://doi.org/10.1016/j.ijhm.2010.03.008

Wiedmann, K. P., Labenz, F., Haase, J., \& Hennigs, N. (2018). The power of experiential marketing: exploring the causal relationships among multisensory marketing, brand experience, customer perceived value and brand strength. Journal of Brand Management, 25(2), 101-118. https://doi.org/10.1057/s41262-017-0061-5

Yang, Y., Gu, Y., \& Galak, J. (2017). When It Could Have Been Worse, It Gets Better: How Favorable Uncertainty Resolution Slows Hedonic Adaptation. Journal of Consumer Research, 43(5), 747-768.

Zarantonello, L., \& Schmitt, B. H. (2010). Using the brand experience scale to profile consumers and predict consumer behaviour. Journal of Brand Management, 17(7), 532-540. https://doi.org/10.1057/bm.2010.4

\section{Copyrights}

Copyright for this article is retained by the author, with first publication rights granted to the journal.

This is an open-access article distributed under the terms and conditions of the Creative Commons Attribution license (http://creativecommons.org/licenses/by/4.0/). 